Review began 01/17/2022 Review ended 01/23/2022 Published 01/24/2022

(c) Copyright 2022

Koh et al. This is an open access article distributed under the terms of the Creative Commons Attribution License CC-BY 4.0. which permits unrestricted use, distribution, and reproduction in any medium, provided the original author and source are credited.

\section{Alcohol Motor Blocks: Case Series and a Narrative Review}

\author{
Moses Koh ${ }^{1}$, Tan Y. Leng ${ }^{2}$ \\ 1. Rehabilitation Medicine/General Medicine, Sengkang General Hospital, Singapore, SGP 2. Rehabilitation Medicine, \\ Singapore General Hospital, Singapore, SGP \\ Corresponding author: Moses Koh, mkoh84@gmail.com
}

\begin{abstract}
Alcohol neurolysis and intramuscular blocks are interventions for spasticity management. Here, we illustrate two clinical cases with spasticity impeding ease of care and pain which required selective alcohol intramuscular blocks with alcohol neurolysis. Post-interventions, both cases demonstrated improvement in pain and joint range of motion which facilitated better positioning and reduced caregiver burden. Pertinent learning points from alcohol neurolysis with intramuscular blocks are discussed concerning therapeutic effectiveness and intervention safety.
\end{abstract}

Categories: Physical Medicine \& Rehabilitation

Keywords: stroke, alcohol motor block, alcohol neurolysis, contractures, spasticity

\section{Introduction}

Alcohol plays an important role in neurolysis and intramuscular blocks for the treatment of spasticity $[1,2]$. Neurolysis using alcohol or phenol has been extensively described in neurorehabilitation; however, intramuscular blocks using these pharmacological injectates have been relatively less discussed. Focal alcohol intramuscular treatment improves spasticity and function in a wide spectrum of conditions ranging from stroke to spinal cord injuries [2,3]. Here, we highlight two clinical cases that demonstrated improved spasticity, joint range of motion (ROM), and pain from focal intramuscular blocks with alcohol guided by nerve stimulator and ultrasound. The first case involved the upper extremities while the latter described lower extremity blocks. In both patients, after alcohol treatment, the clinical improvements were sustained at six weeks and three months. Moreover, the respective caregivers reported easier nursing care.

\section{Case Presentation}

\section{Case one}

A 76-year-old gentleman (Mr. S) suffered from bilateral posterior circulation infarcts. He was on outpatient rehabilitation follow-up at our hospital. One year after the stroke, he was assessed to have worsening bilateral upper limb spasticity, pain on passive ranging, and his upper extremities were kept in a flexed and adducted position (Figures 1, Panel a). His caregiver encountered difficulty in upper body dressing and hygiene care. 


\section{Cureus}

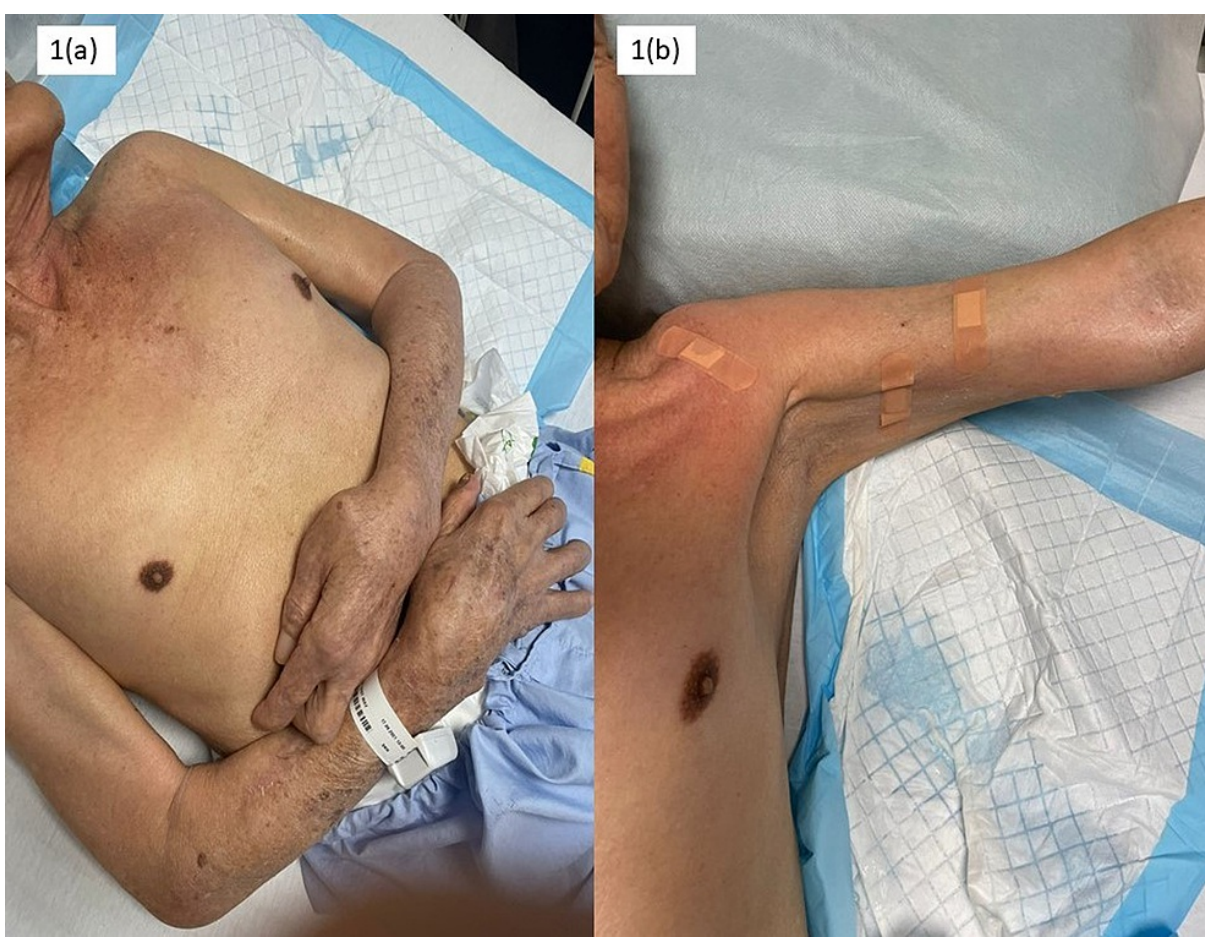

\section{FIGURE 1: Clinical photos illustrating left upper extremity posture pre}

and post-alcohol neurolysis and intramuscular nerve blocks.

(a) Pre-injection; (b) post-injection.

Physical Findings

The patient was unable to perform any active ROM of the shoulder, elbow, thumb, and finger flexors. On examination, the strength of the upper extremities using manual muscle testing (MMT) was as follows: (a) right shoulder abduction $0 / 5$, right elbow flexion and extension $0 / 5$, right wrist flexion and extension $0 / 5$, and right finger and thumb extension $0 / 5$; and (b) left shoulder abduction $0 / 5$, left elbow flexion and extension $0 / 5$, left wrist flexion and extension $0 / 5$, and left finger and thumb extension $0 / 5$.

Passive shoulder abduction ROM was assessed to be $45^{\circ}$ bilaterally. His left elbow extension ROM was assessed to be $-90^{\circ}$, left wrist extension ROM was $0^{\circ}$, and left finger and thumb extension ROM was $-45^{\circ}$. Moreover, his bilateral shoulder adductor, left elbow flexor tone, left wrist flexors, and thumb and finger flexors demonstrated spasticity on the Modified Tardieu Scale as follows: (a) shoulder adductor: fast passive movement (R1) was $20^{\circ}$ and slow passive movement (R2) was $45^{\circ}$; (b) left elbow flexor: R1 was $90^{\circ}$ and R2 was $135^{\circ}$; (c) left thumb flexor: R1 was $45^{\circ}$ and R2 was $90^{\circ}$; (d) left finger flexors: R1 was $20^{\circ}$ and R2 was $45^{\circ}$.

We further assessed the left shoulder using sonographic assessment which did not suggest any ultrasound features of adhesive capsulitis which might have contributed to the shoulder-restricted ROM.

\section{Clinical Management}

The patient received a comprehensive rehabilitation program, which included three months of inpatient rehabilitation. The program consisted of intensive daily stretching and strengthening exercises, neuromuscular electrical stimulation, activities of daily living (ADL) training, as well as caregiver training to continue stretching exercises at home. He was assessed to be unsuitable for oral antispasmodic agents such as Baclofen in view of increased daytime drowsiness and somnolence during his inpatient stay and at home. He was also not agreeable for orthotic splints to be applied due to pain and discomfort.

Despite receiving a rehabilitation program, the patient remained symptomatic for his regional spasticity, reporting pain and spasms on performing his ADL. Given the difference in R2-R1 indicating the dynamic component of the spasticity, an informed decision was made to administer alcohol injections to the selected muscles and neurolysis to the nerves involved. Specifically, bilateral pectoralis major intramuscular alcohol blocks and alcohol neurolysis of his left musculocutaneous and left median nerves were performed. Botulinum toxin with alcohol neurolysis was discussed with the patient and his family but was 


\section{Cureus}

declined due to financial concerns.

\section{Specifics of the Intervention}

We administered $75 \%$ alcohol (15 mL of $100 \%$ dehydrated alcohol with $5 \mathrm{~mL}$ of $1 \%$ lignocaine). The left musculocutaneous nerve was targeted using ultrasound guidance between the biceps and brachialis with 5 $\mathrm{mL}$ of $75 \%$ alcohol. Similarly, the median nerve was targeted with ultrasound guidance using an equal amount of alcohol. The initial intention was to further target the lateral pectoral nerve for relieving shoulder adductor spasticity; however, the patient could not tolerate shoulder positioning (shoulder external rotation) to facilitate better visualization of both the lateral pectoral nerves. As such, a decision was made to proceed with $2.5 \mathrm{~mL}$ of $75 \%$ alcohol/lignocaine in each of the pectoralis major muscles (Figures $2 a-2 c$ ).

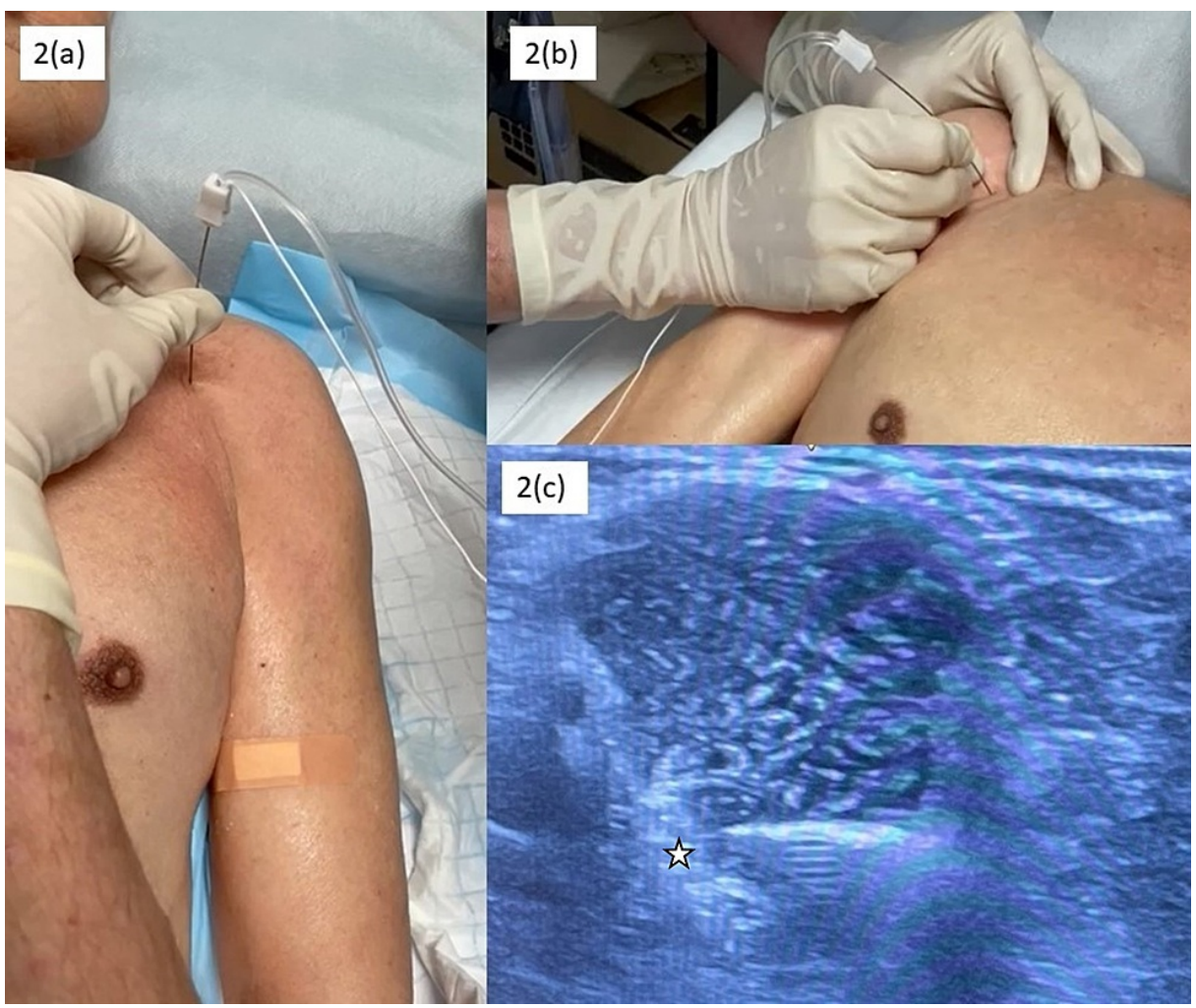

FIGURE 2: Clinical photos illustrating the procedures.

(a) Motor point alcohol injection of the left pectoralis major using nerve stimulator of current between 1 and $2 \mathrm{~mA}$. (b) Motor point alcohol injection of the right pectoralis major. (c) Ultrasound image illustrating alcohol neurolysis of the musculocutaneous nerve.

The images show the needle entry via in-plane injection technique advancing toward the star indicating the location of the musculocutaneous nerve.

Outcomes

Immediately post-intervention, improvement in the right shoulder adductor and left upper extremity spasticity was noted (Figure 1, Panel b). Six weeks and three months after the intervention, spasticity and joint ROM were improved, indicating the positive therapeutic effect of alcohol on spasticity of the upper extremities. The caregiver reported easier daily nursing care such as upper body dressing, bed to chair transfer, and better hygiene care of the skin of the axilla, elbow, and palm at six weeks and three months. In addition, there was an improvement in bilateral upper limb strength at six weeks and three months with MMT as follows: (a) right shoulder abduction 2/5, right elbow flexion and extension 2/5, right wrist flexion and extension $2 / 5$, and right finger and thumb extension $2 / 5$; and (b) left shoulder abduction $1 / 5$, left elbow flexion and extension $1 / 5$, left wrist flexion and extension $1 / 5$, and left finger and thumb extension $1 / 5$.

\section{Case two}

A 64-year-old gentleman (Mr. A) suffered from bilateral spastic paraparesis secondary to ossification of the posterior longitudinal ligament and T10-T11 cord indentation and was bed and chair-bound. On an inpatient review four months after the initial diagnosis, he was assessed to have spasticity of his bilateral 


\section{Cureus}

lower limbs, which kept him in a flexed position (Figure 3, Panel a). There was pain during the transfer from the bed to the wheelchair, and the caregiver encountered challenges in lower body dressing due to flexed knee and skincare of the popliteal fossa.

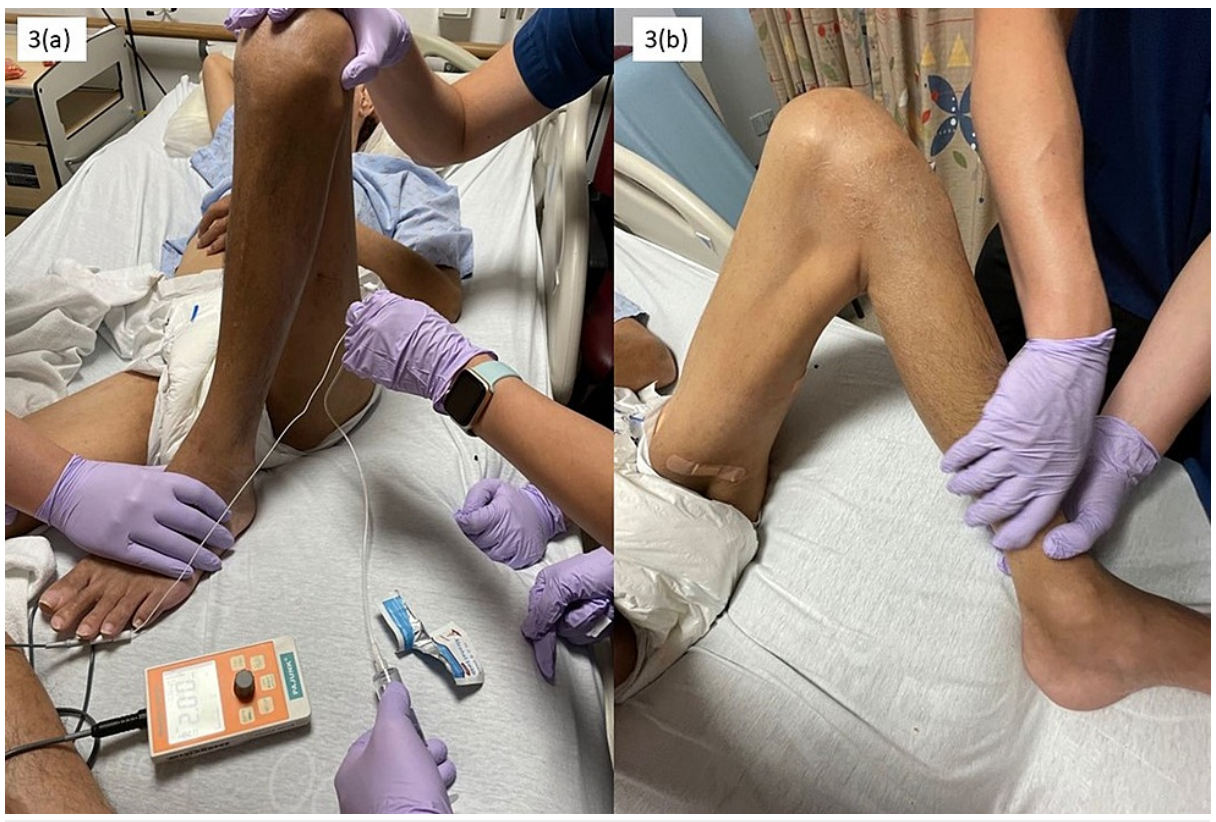

FIGURE 3: Clinical photos illustrating alcohol motor point injection of the left hamstrings and left knee extension passive ROM pre and postinjection.

(a) Pre-injection; (b) post-injection

Physical Findings

No active ROM for the right hip and knee were elicited. The passive ROM was as follows: (a) right hip extension was $-80^{\circ}$, and left hip extension was $-90^{\circ}$; (b) right knee extension was $-140^{\circ}$, and left knee extension was $-170^{\circ}$; and (c) bilateral ankle dorsiflexion was $0^{\circ}$.

Spasticity was noted in both the right hip and knee flexors using the Modified Tardieu Scale as follows: (a) right knee flexor: R1 was $30^{\circ}$ and R2 was $80^{\circ}$; (b) left knee flexors: R1 was $20^{\circ}$ and R2 was $45^{\circ}$.

\section{Clinical Management}

The patient received inpatient physiotherapy which included bilateral lower limb stretching and strengthening exercises. He was given a trial of oral spasmodic agents baclofen and tizanidine, which did not result in significant improvement of his spasticity or ROM. He was not suitable for orthotic splints due to severe pain experienced even on slight passive stretching. The patient experienced severe pain from spasticity on performing his ADL and when assisted by the caregiver. He declined botulinum toxin administration to the hamstrings due to the cost involved.

An informed decision was made to perform alcohol neurolysis to the sciatic nerves but the patient declined perineural nerve injection. Upon further discussion, he accepted an alternative strategy of targeting bilateral hamstring major motor points with alcohol.

\section{Specifics of the Intervention}

We administered $15 \mathrm{~mL}$ of $100 \%$ dehydrated alcohol diluted with $5 \mathrm{~mL}$ of $1 \%$ Lignocaine (75\% alcohol). The stimuplex needle was inserted into bilateral hamstring motor points using $2 \mathrm{~mL}$ of $75 \%$ alcohol/lignocaine per motor point (Figures $4 a, 4 b$ ). 


\section{Cureus}

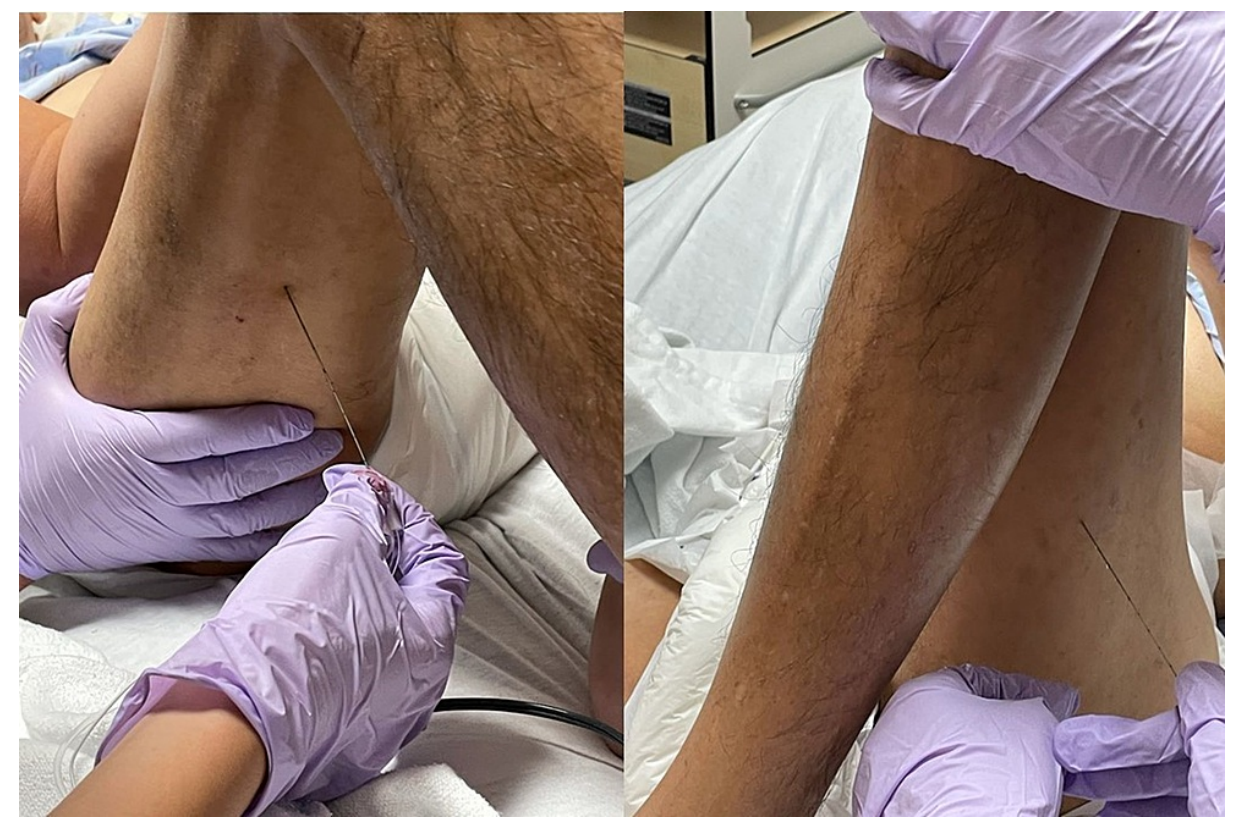

FIGURE 4: Clinical photos illustrating alcohol motor point injection of bilateral hamstrings.

(a) Right hamstring alcohol motor point injection; (b) left hamstring alcohol motor point injection.

Outcomes

Immediately post-intervention, improvement was noted on the Modified Tardieu Scale, knee ROM, and pain (Figure 3, Panel b). At two weeks, we noted sustained improvement. Table 1 summarizes the outcomes of both patients after the interventions. 


\section{Cureus}

\begin{tabular}{|c|c|c|c|c|c|}
\hline & Spasticity & Joint ROM & Pain & MMT & Adverse events \\
\hline $\begin{array}{l}\text { Mr. S } \\
\text { immediate } \\
\text { post- } \\
\text { treatment }\end{array}$ & $\begin{array}{l}\text { Left shoulder: R1, } 45^{\circ} \text {, } \\
\text { R2, } 90^{\circ} \text {. Left elbow } \\
\text { flexor: R1, } 120^{\circ}, \mathrm{R} 2 \text {, } \\
160^{\circ} \text {. Left thumb flexor: } \\
\text { R1, } 80^{\circ}, \mathrm{R} 2,100^{\circ} \text {. Left } \\
\text { finger flexor: R1, } 45^{\circ} \text {, } \\
\text { R2, } 80^{\circ}\end{array}$ & $\begin{array}{l}\text { Left shoulder } \\
\text { abduction: } 90^{\circ} \text {. Left } \\
\text { shoulder extension: - } \\
20^{\circ} \text {. Left wrist } \\
\text { extension: } 30^{\circ} \text {. Left } \\
\text { thumb extension: } 10^{\circ} \text {. } \\
\text { Left finger extension: - } \\
10^{\circ}\end{array}$ & $\begin{array}{l}\text { VAS } \\
3 / 10\end{array}$ & $\begin{array}{l}\text { Right shoulder abduction 0/5. Right elbow } \\
\text { flexion and extension 0/5. Right wrist flexion } \\
\text { and extension } 0 / 5 \text {. Right finger and thumb } \\
\text { extension } 0 / 5 \text {. Left shoulder abduction } 0 / 5 \text {. } \\
\text { Left elbow flexion and extension 0/5. Left wrist } \\
\text { flexion and extension 0/5. Left finger and } \\
\text { thumb extension 0/5 }\end{array}$ & \multirow{3}{*}{$\begin{array}{l}\text { No edema, } \\
\text { hematoma, or } \\
\text { hyperesthesia was } \\
\text { noted at all follow- } \\
\text { ups }\end{array}$} \\
\hline $\begin{array}{l}\text { Mr. S at } \\
\text { six weeks }\end{array}$ & $\begin{array}{l}\text { Left shoulder: R1, } 45^{\circ} \text {, } \\
\text { R2, } 90^{\circ} \text {. Left elbow } \\
\text { flexor: R1, } 120^{\circ}, \text { R2, } \\
160^{\circ} \text {. Left thumb flexor: } \\
\text { R1, } 80^{\circ}, \text { R2, } 100^{\circ} \text {. Left } \\
\text { finger flexor: R1, } 45^{\circ} \text {, } \\
\text { R2, } 80^{\circ}\end{array}$ & $\begin{array}{l}\text { Left shoulder } \\
\text { abduction: } 90^{\circ} \text {. Left } \\
\text { shoulder extension: - } \\
20^{\circ} \text {. Left wrist } \\
\text { extension: } 30^{\circ} \text {. Left } \\
\text { thumb extension: } 10^{\circ} \text {. } \\
\text { Left finger extension: - } \\
10^{\circ}\end{array}$ & $\begin{array}{l}\text { VAS } \\
2 / 10\end{array}$ & $\begin{array}{l}\text { Right shoulder abduction } 2 / 5 \text {. Right elbow } \\
\text { flexion and extension } 2 / 5 \text {. Right wrist flexion } \\
\text { and extension } 2 / 5 \text {. Right] finger and thumb } \\
\text { extension } 2 / 5 \text {. Left shoulder abduction } 1 / 5 \text {. } \\
\text { Left elbow flexion and extension } 1 / 5 \text {. Left wrist } \\
\text { flexion and extension } 1 / 5 \text {. Left finger and } \\
\text { thumb extension } 1 / 5 \text {. }\end{array}$ & \\
\hline $\begin{array}{l}\text { Mr. S at } \\
\text { three } \\
\text { months }\end{array}$ & $\begin{array}{l}\text { Left shoulder: R1, } 70^{\circ} \text {, } \\
\text { R2, } 100^{\circ} \text {. Left elbow } \\
\text { flexor: R1, } 120^{\circ}, \text { R2, } \\
160^{\circ} \text {. Left thumb flexor: } \\
\text { R1, } 80^{\circ}, \text { R2, } 100^{\circ} \text {. Left } \\
\text { finger flexor: R1, } 60^{\circ} \text {, } \\
\text { R2: } 90^{\circ}\end{array}$ & $\begin{array}{l}\text { Left shoulder } \\
\text { abduction: } 100^{\circ} \text {. Left } \\
\text { shoulder extension: - } \\
20^{\circ} \text {. Left wrist } \\
\text { extension: } 30^{\circ} \text {. Left } \\
\text { thumb extension: } 10^{\circ} \text {. } \\
\text { Left finger extension: } \\
0^{\circ}\end{array}$ & $\begin{array}{l}\text { VAS } \\
2 / 10\end{array}$ & $\begin{array}{l}\text { Right shoulder abduction } 2 / 5 \text {. Right elbow } \\
\text { flexion and extension } 2 / 5 \text {. Right wrist flexion } \\
\text { and extension } 2 / 5 \text {. Right finger and thumb } \\
\text { extension } 2 / 5 \text {. Left shoulder abduction } 1 / 5 \text {. } \\
\text { Left elbow flexion and extension } 1 / 5 \text {. Left wrist } \\
\text { flexion and extension } 1 / 5 \text {. Left finger and } \\
\text { thumb extension } 1 / 5\end{array}$ & \\
\hline $\begin{array}{l}\text { Mr. A } \\
\text { immediate } \\
\text { post- } \\
\text { treatment }\end{array}$ & $\begin{array}{l}\text { Right knee flexor: R1, } \\
45^{\circ}, \mathrm{R} 2,90^{\circ} \text {. Left knee } \\
\text { flexor: R1, } 40^{\circ}, \mathrm{R} 2: 80^{\circ}\end{array}$ & $\begin{array}{l}\text { Right knee extension: - } \\
90^{\circ} \text {. Left knee } \\
\text { extension: -100 }\end{array}$ & $\begin{array}{l}\text { VAS } \\
5 / 10\end{array}$ & $\begin{array}{l}\text { Bilateral hip flexion/extension 0/5. Bilateral } \\
\text { knee flexion/extension 0/5. Bilateral ankle } \\
\text { dorsiflexion and plantarflexion 0/5 }\end{array}$ & \multirow{2}{*}{$\begin{array}{l}\text { No hematoma or } \\
\text { hyperesthesia was } \\
\text { noted at all follow- } \\
\text { ups. There was } \\
\text { only transient pain } \\
\text { experienced during } \\
\text { the procedure }\end{array}$} \\
\hline $\begin{array}{l}\text { Mr. A at } \\
\text { two } \\
\text { weeks }\end{array}$ & $\begin{array}{l}\text { Right knee flexor: R1, } \\
45^{\circ}, \mathrm{R} 2,90^{\circ} \text {. Left knee } \\
\text { flexor: R1, } 40^{\circ}, \mathrm{R} 2,80^{\circ}\end{array}$ & $\begin{array}{l}\text { Right knee extension: - } \\
90^{\circ} \text {. Left knee } \\
\text { extension: }-100^{\circ}\end{array}$ & $\begin{array}{l}\text { VAS } \\
5 / 10\end{array}$ & $\begin{array}{l}\text { Bilateral hip flexion/extension 0/5. Bilateral } \\
\text { knee flexion/extension 0/5. Bilateral ankle } \\
\text { dorsiflexion and plantarflexion 0/5 }\end{array}$ & \\
\hline
\end{tabular}

\section{TABLE 1: Outcomes of Mr. S and Mr. A after interventions with alcohol.}

ROM: range of motion; VAS: Visual Analogue Scale

\section{Discussion}

Motor point block using phenol or alcohol has been described in the treatment of spasticity [3,4]. A summary of selected studies describing alcohol motor blocks is presented in Table 2. 


\section{Cureus}

\begin{tabular}{|c|c|c|c|c|c|c|c|}
\hline $\begin{array}{l}\text { Author and } \\
\text { year of } \\
\text { publication }\end{array}$ & $\begin{array}{l}\text { Study } \\
\text { design }\end{array}$ & $\begin{array}{l}\text { Number } \\
\text { of } \\
\text { patients }\end{array}$ & $\begin{array}{l}\text { Types of } \\
\text { intervention } \\
\text { described }\end{array}$ & $\begin{array}{l}\text { Percentages } \\
\text { of alcohol } \\
\text { used }\end{array}$ & Injection guide & $\begin{array}{l}\text { Outcome } \\
\text { measures }\end{array}$ & $\begin{array}{l}\text { Adverse } \\
\text { effects }\end{array}$ \\
\hline $\begin{array}{l}\text { Uchikawa } \\
\text { et al. } 2008 \\
{[10]}\end{array}$ & $\begin{array}{l}\text { A cohort } \\
\text { study on } \\
\text { spinal cord } \\
\text { injury } \\
\text { patients with } \\
\text { neurological } \\
\text { level of } \\
\text { injury at C5 }\end{array}$ & 7 & $\begin{array}{l}\text { Subscapularis } \\
\text { motor block) }\end{array}$ & $\begin{array}{l}0.2-0.3 \mathrm{~mL} \\
\text { of } 5 \% \\
\text { phenol }\end{array}$ & $\begin{array}{l}\text { Surface landmarks. Patients were } \\
\text { positioned on one side, with the arms } \\
\text { propped to produce as much winging } \\
\text { of the scapula as possible. The } \\
\text { needle was inserted under the medial } \\
\text { edge of the scapula at the level of the } \\
\text { spine of the scapula with electrical } \\
\text { stimulation of } 1 \text { mA to locate the } \\
\text { motor point }\end{array}$ & $\begin{array}{l}\text { Improved } \\
\text { shoulder flexion, } \\
\text { passive ROM } \\
\text { abduction, } \\
\text { external rotation, } \\
\text { VAS, and eating } \\
\text { FIM. No } \\
\text { improvement } \\
\text { noted in the } \\
\text { shoulder MAS } \\
\text { scores }\end{array}$ & Nil \\
\hline $\begin{array}{l}\text { Kong and } \\
\text { Chua } 2002 \\
{[3]}\end{array}$ & $\begin{array}{l}\text { A cohort } \\
\text { study of } \\
\text { post-stroke } \\
\text { patients with } \\
\text { finger flexor } \\
\text { spasticity }\end{array}$ & 30 & $\begin{array}{l}\text { Flexor carpi } \\
\text { ulnaris, flexor } \\
\text { carpi radialis, } \\
\text { flexor digitorum } \\
\text { superficialis, flexor } \\
\text { digitorum } \\
\text { profundus, and } \\
\text { the flexor pollicis } \\
\text { longus }\end{array}$ & $\begin{array}{l}50 \% \text { ethyl } \\
\text { alcohol }\end{array}$ & $\begin{array}{l}\text { Surface localization of motor points } \\
\text { using standard electromyogram texts } \\
\text { and use of neuromuscular stimulator } \\
\text { with a current of } 1 \mathrm{~mA} \text { or less }\end{array}$ & $\begin{array}{l}\text { Improvement in } \\
\text { MAS, finger ROM } \\
\text { at four weeks, } \\
\text { three months, and } \\
\text { six months but no } \\
\text { improvement in } \\
\text { motor control }\end{array}$ & $\begin{array}{l}\text { Dysesthesia } \\
\text { lasting for } \\
\text { an average } \\
\text { of one week }\end{array}$ \\
\hline
\end{tabular}

TABLE 2: A summary of studies on the employment of alcohol intramuscular blocks in the treatment of spasticity.

VAS: Visual Analogue Scale; MAS: Modified Ashworth Scale; FIM: Functional Independence Measure

Alcohol or phenol offers several advantages in spasticity management [5], and the rapid onset facilitates serial casting. Alcohol or phenol cost less than botulinum toxins, have therapeutic effects on the sensory fibers to further reduce the spasticity reflex arc, and demonstrate potency on large muscle groups [5].

\section{The concentration of alcohol or phenol used}

In both of our cases, we utilized $75 \%$ alcohol. A wide range of alcohol concentrations, namely, ethanol (50$100 \%$ ) and phenol (5-12\%), have been reported to be effective in post-stroke spasticity [3,4,6,7]. A higher concentration of alcohol was utilized in these two cases aiming for more permanent blocks due to their poor functional prognosis [3]. Ultimately, the concentration of alcohol used determines the extent of action, and the experience of the clinician is a crucial factor [5]. With higher concentrations of alcohol, a more marked inflammatory response can be noted [1].

For phenol, concentrations of greater than 3\% phenol should be used. At these higher concentrations, phenol causes Wallerian degeneration and axonal demyelination leading to muscle denervation $[1,8]$. Low phenol concentrations (less than 3\%) would only achieve a reversible anesthetic effect $[1,9]$.

\section{Choice of the target sites}

The combined use of alcohol neurolysis and intramuscular blocks assisted in achieving the therapeutic outcomes. In Mr. S, the pectoris major was easily accessible and targeted using motor point blocks, while musculocutaneous and median neurolysis was more suitable for forearm and finger spasticity. For Mr. A, the aim was to reduce spasticity of knee flexors, and rather than targeting the sciatic nerve, local intramuscular blockade of the hamstring complex offered an easier alternative approach.

\section{Therapeutic outcomes}

We observed improved spasticity and targeted joint ROM in both patients. For Mr. S, reduced pain and spasm facilitated better hygiene care of the upper extremity with intramuscular alcohol blocks and neurolysis. Likewise, for Mr. A, intramuscular alcohol blocks alone were able to achieve a better sitting posture. With the immediate therapeutic outcomes observed, physicians can consider the prompt implementation of other modalities such as splinting or serial castings [5]. In both patients, physical therapy, stretching, and positioning after the alcohol procedures were able to achieve the therapeutic goals, and hence, serial castings were not necessary. 


\section{Cost consideration}

Where sources of funding might not be easily accessible for botulinum toxin, combined alcohol intramuscular blocks and neurolysis is a feasible option.

\section{Adverse events}

None of the two patients developed any serious adverse effects at higher concentrations of alcohol (75\%), which is consistent with a previous study [1]. None of the two illustrated cases were on oral anticoagulants.

\section{Learning points}

Motor point blocks with neurolysis are reasonable modalities to treat spasticity. Clinicians need to be trained in alcohol neurolysis and intramuscular blocks using nerve stimulators and/or sonography guidance. Certain muscles (such as hamstrings and pectoris majors) are easily targeted rather than neurolysis of the nerve. Conversely, elbow and forearm flexors consist of many muscles, and neurolysis should be considered. Second, the cost of large doses of botulinum toxin at each intervention setting can potentially be overcome by adding alcohol as a treatment modality. Botulinum toxins might not be a major concern in regions where comprehensive healthcare funding exists. In countries where funding is a concern, clinicians should appropriately consider alcohol injectates. Third, it might be useful in the subgroup of patients who are nonresponders to botulinum toxin. Lastly, clinicians should be aware of adverse effects such as temporary dysesthesia, neuropathic pain, or edema post-intervention.

\section{Conclusions}

We illustrated the effectiveness of using alcohol intramuscular blocks with neurolysis for spasticity management in a select group of patients where choice and cost of botulinum neurotoxin are a concern. Clinicians should explore alcohol intramuscular blocks together with neurolysis as part of the overall spasticity armamentarium when pain and function remain suboptimal despite physical therapy, and/or physical modalities to assist in positioning, and after trials of botulinum neurotoxins. This intervention is safe but clinicians should be mindful of the potential adverse effects.

\section{Additional Information \\ Disclosures}

Human subjects: Consent was obtained or waived by all participants in this study. Conflicts of interest: In compliance with the ICMJE uniform disclosure form, all authors declare the following: Payment/services info: All authors have declared that no financial support was received from any organization for the submitted work. Financial relationships: All authors have declared that they have no financial relationships at present or within the previous three years with any organizations that might have an interest in the submitted work. Other relationships: All authors have declared that there are no other relationships or activities that could appear to have influenced the submitted work.

\section{Acknowledgements}

Moses Koh and Yeow Leng Tan contributed equally to the work and should be considered co-first authors.

\section{References}

1. Zafonte RD, Munin MC: Phenol and alcohol blocks for the treatment of spasticity. Phys Med Rehabil Clin N Am. 2001, 12:817-32, vii.

2. Lui J, Sarai M, Mills PB: Chemodenervation for treatment of limb spasticity following spinal cord injury: a systematic review. Spinal Cord. 2015, 53:252-64. 10.1038/sc.2014.241

3. Kong KH, Chua KS: Intramuscular neurolysis with alcohol to treat post-stroke finger flexor spasticity . Clin Rehabil. 2002, 16:378-81. 10.1191/0269215502cr508oa

4. McCrea PH, Eng JJ, Willms R: Phenol reduces hypertonia and enhances strength: a longitudinal case study Neurorehabil Neural Repair. 2004, 18:112-6. 10.1177/08884390042265662

5. Elovic EP, Esquenazi A, Alter KE, Lin JL, Alfaro A, Kaelin DL: Chemodenervation and nerve blocks in the diagnosis and management of spasticity and muscle overactivity. PM R. 2009, 1:842-51. 10.1016/j.pmrj.2009.08.001

6. Ghai A, Sangwan SS, Hooda S, Kiran S, Garg N: Obturator neurolysis using $65 \%$ alcohol for adductor muscle spasticity. Saudi J Anaesth. 2012, 6:282-4. 10.4103/1658-354X.101223

7. Viel E, Pellas F, Ripart J, Pélissier J, Eledjam JJ: [Peripheral neurolytic blocks and spasticity]. Ann Fr Anesth Reanim. 2005, 24:667-72. 10.1016/j.annfar.2005.03.015

8. Bodine-Fowler SC, Allsing S, Botte MJ: Time course of muscle atrophy and recovery following a phenolinduced nerve block. Muscle Nerve. 1996, 19:497-504. 10.1002/mus.880190404

9. DeLateur BJ: A new technique of intramuscular phenol neurolysis . Arch Phys Med Rehabil. 1972, 53:179-81 passim.

10. Uchikawa K, Toikawa H, Liu M: Subscapularis motor point block for spastic shoulders in patients with cervical cord injury. Spinal Cord. 2009, 47:249-51. 10.1038/sc.2008.122 